\title{
Textbooks, Postcards, and the Public Consolidation of Nationalism in Latin America
}

\author{
Anna Kyriazi ${ }^{1} \cdot$ Matthias vom $\mathrm{Hau}^{2}$ (ID \\ Published online: 15 August 2020 \\ (C) The Author(s) 2020
}

\begin{abstract}
The existing macro-historical scholarship tends to assert rather than demonstrate the wider impact of nationalism. Yet, state-sponsored national ideologies permeate the broader reaches of society to varying degrees. To investigate variations in the consolidation of official nationalism, this paper combines the content analysis of school textbooks as state-regulated and picture postcards as primarily marketdriven sources. Building on this novel methodological approach, we find that textbooks published in mid-twentieth-century Argentina, Mexico, and Peru promoted a similar popular nationalism that portrayed the lower classes as "true" national subjects. However, picture postcards from the same period demonstrate that the consolidation of this official national ideology varied. In Mexico and Peru, the new state-sponsored conceptions of nationhood gained presence in public life, but they did not to take hold in Argentina. We conclude that studying the top-down nationalist messages promoted by states should not be equated with studying their ideological impact in public life.
\end{abstract}

Keywords Nationalism · Ideology · Visual analysis · Education · Latin America

Electronic supplementary material The online version of this article (https://doi.org/10.1007/s11133-02009467-8) contains supplementary material, which is available to authorized users.

Anna Kyriazi

anna.kyriazi@unimi.it

Matthias vom Hau

mvomhau@ibei.org

1 Department of Social and Political Sciences, Università degli Studi di Milano, via Conservatorio 7, 20122 Milan, Italy

2 Institut Barcelona d'Estudis Internacionals (IBEI), Ramon Trias Fargas 25-27, 08005 Barcelona, Spain 


\section{Introduction}

It is by now well established that states have played a crucial role in the production and dissemination of nationalism. State institutions - whether public education (Gellner 1983; Hobsbawm 1990; Smith 1986), census taking (Loveman 2014), or social provision (Wimmer 2018) - have been shown to be pivotal in the shift from a world in which national ideologies and attachments were unthinkable to a world in which nationalism has become the dominant form of political organization and collective identification.

But it is equally well established that state-orchestrated representations of the nation do not necessarily have much in common with those found in public culture and everyday life (Brubaker et al. 2006; Edensor 2002). In fact, the existing macro-historical scholarship often asserts rather than empirically demonstrates the wider consolidation of nationalism. Ernest Gellner (1983), for example, suggests that all-powerful state organizations imposed nationallydefined cultural forms and identities on subjects; Eric Hobsbawm and Terence Ranger (1983) similarly emphasize the top-down inculcation of distinct "national" traditions and ideological outlooks. A major problem of this line of reasoning is that it treats the expansion of state power as shorthand for widespread national indoctrination, thereby conflating institutional development with ideological impact.

This problem can also be found in scholarship that is more specifically concerned with the role of mass education as the nationalizing institution of the state. Many of these studies equate the expansion of public schooling across national territory with the successful national socialization of the citizenry (e.g., Darden and Mylonas 2016; Gellner 1983). And even those studies that unpack the "black box" of schooling to explore the reception of official educational contents among teachers and students (e.g., Vaughan 1997; vom Hau 2009; Weber 1976) often remain confined to the realm of education and do not systematically explore the wider imposition and circulation of official national ideologies outside the sphere of immediate state control.

Not surprisingly, a growing body of work has started to explore how nationalism as an institutionalized ideology promoted by the state relates to understandings of nationhood found in everyday and public life (Brubaker et al. 2006; Fox and Miller-Idriss 2008; Malešević 2019). Scholars investigate when ordinary citizens feel national (Skey 2011; Antonsich 2016) and how they respond to particular official representations of the nation (Miller-Idriss 2009). Analysts also explore the extent to which official understandings of nationhood circulate in widely-shared cultural forms and products (Billig 1995; Edensor 2002). When addressing these methodologically challenging issues, this literature has employed a variety of strategies, including but not limited to investigating the symbols and iconographies of nationhood found in public spaces (Edensor 2002), used in identity talk (Miller-Idriss 2009), or enacted in recreational rituals (Surak 2012). In doing so, scholars have made creative use of a variety of different sources of evidence, most prominently semi-structured interviews, focus groups, participant observation, and participatory photography (see Fox and van Ginderachter 2018).

Historical analyses of the connections between official nationalism and representations of the nation that prevail in everyday and public life face even greater methodological challenges, not the least because it is simply not possible to interview, observe, or give cameras anymore to those who are already dead. Nonetheless, considerable scholarship has recently emerged that takes up this daring task and employs a variety of innovative methods and sources to study when state-sponsored national ideologies infuse broader reaches of society during historical 
periods (Judson 2006; King 2002; Van Ginderachter 2019b; Zahra 2008). In this article we build on yet also move beyond this literature. The majority of these historical studies explore the extent to which official nationalism - as an ideological form - is internalized by the public or, alternatively, is met by national indifference (Van Ginderachter 2019a, 4-9). In this article, by contrast, we focus on the ideological contents of official nationalism and explore the extent to which a new (or changed) state-sponsored national ideology permeates public culture more broadly. And whereas most of the existing works on this issue are based on individual historical case studies, we develop a novel conceptual framework and empirical research strategy for conducting systematic comparative research.

In doing so, our study combines insights from institutional and Gramscian approaches to cultural analysis to identify variations in the consolidation of official nationalism in public culture. We also introduce a new combination of empirical sources into the historical analysis of nationalism. We first draw on civic education and history school textbooks used in primary education to map state-led imposition of official understandings of nationhood. Textbooks are a particularly suitable source for this endeavor because they capture - at least for the late nineteenth and the twentieth century - the long-term visions of national identity and history states seek to convey. We then use picture postcards to investigate the liberal circulation of state-sponsored conceptions of nationhood in public life. Postcards are an unconventional and underexplored source for the historical study of nationalism, despite the fact that they constitute a particularly suitable window to the public prevalence of official ideological content. ${ }^{1}$ Crucially, as a visual medium, postcards are on constant display, thereby signaling particular understandings of nationhood across the national territory. Moreover, their production has been primarily market-driven and tailored predominantly towards commercial mass culture rather than being directly shaped by state control.

To illustrate the empirical usefulness of this methodological strategy, we contrast historical patterns of nationalism in mid-twentieth-century Mexico, Peru, and Argentina. Our focus on cases from Latin America is part of a broader repositioning effort to address the relative absence of systematic comparative studies on nationalism in the extra-European world (Bayly 2004, 199). Mexico, Peru, and Argentina were chosen because the three countries represent likely extreme points in the region. Mexico and Peru are broadly similar in their colonial legacies and levels of ethnic diversity, while Argentina provides a sharp contrast. As centers of Spanish colonialism, the territories corresponding to modern Mexico and Peru saw the creation of mercantile actors and ethno-racial stratification systems, with large implications for subsequent patterns of state- and nation-building. At the same time, Mexico and Peru followed very different trajectories of political development during the late nineteenth and early twentieth century. As a settler society with massive European migration and a former colonial backwater, the region corresponding to modern Argentina played only a marginal role in the Spanish colonial system, which facilitated postcolonial incorporation into the global capitalist economy. Similar to Peru, however, in postcolonial Argentina, political development was characterized by instability and repeated transitions from authoritarianism to democracy (Collier and Collier 1991; Mahoney 2010).

Despite these differences, our school textbook analysis reveals that during the mid-twentieth-century, Mexico, Peru, and Argentina exhibited striking similarities in their respective

\footnotetext{
${ }^{1}$ Studies linking various manifestations of visual culture with prevailing conceptions of nationhood are, of course, ubiquitous. Our work seeks to make explicit the comparisons implicit in such analyses, offering a complete methodological framework that enables more systematic research.
} 
official national ideologies. In all three countries, state leaders adopted a popularassimilationist nationalism. The nation appeared as grounded in the notion of a common ancestry, as well as cultural features, such as a shared language or religion, while national unity was to be achieved through assimilation into this national culture. This popular-assimilationist nationalism portrayed subordinate sectors as "true" nationals, whereas the "oligarchy" was marked as antagonistic to national interests, and therefore did not fully belong to the national community. Accordingly, accounts of national history became centered on popular agency and celebrated the role of the masses in shaping the historical trajectory of the nation.

Yet, our study of postcards shows that the consolidation of this new official national ideology varied. In Mexico and, to a somewhat lesser extent in Peru, popular-assimilationist nationalism also manifested itself in more broadly shared images and narratives found in public life. In Argentina, state leaders managed to install the new nationalism as a regular product of state organizations, but its circulation in the wider public sphere was limited. Postcards remained primarily infused with the previously prevailing liberal-elitist national ideology, which fused Enlightenment ideals of political citizenship with highly exclusionary and hierarchical visions of the national community.

Before we proceed, an important disclaimer is warranted. Our research strategy is not tailored towards identifying historical patterns of everyday nationalism —or the experience of nationhood by ordinary people, and especially not those living in the past (Fox and MillerIdriss 2008; Knott 2016). ${ }^{2}$ Postcards do not allow us to crawl into the brains of ordinary citizens in order to understand how they consumed the images conveyed on postcards, and whether they challenged or embraced official conceptions of national identity and history. ${ }^{3}$ They also do not allow us to investigate when ordinary people felt national and when they did not, or when they rejected the nation as a relevant category of identification. Rather, for the context of late nineteenth- to mid-twentieth-century Latin America, postcards provide a window into what postcard creators, photographers, and publishers, as commercial culture producers situated outside the sphere of immediate state control, might have perceived as the everyday understandings of nationhood held by ordinary citizens.

The remainder of the paper develops our argument in greater detail. The next section discusses the conceptual framework, while the third one develops our empirical approach and the rationale for comparing school textbooks and picture postcards to study variations in the public consolidation of official nationalism. The subsequent two sections provide the necessary background on textbook and postcard production in Latin America, discuss our data collection and analytical strategies, and present the main results. The conclusion spells out the wider implications of our study for the empirical study of nationalism, ideological change, and visual sociology.

\section{The Consolidation of a New Official Nationalism: A Conceptual Framework}

How can we understand differences in the extent to which a new (or changed) state-sponsored national ideology gains presence in public culture more broadly conceived? This section

\footnotetext{
2 The distinction between public (whether official or not) and everyday nationalism echoes recent debates in the sociology of culture around the distinction between public and personal culture (Lizardo 2017; Patterson 2014).

${ }^{3} \mathrm{We}$ are thankful to one of the anonymous reviewers for this poignant formulation.
} 
develops an analytical model that combines insights derived from an institutional approach to cultural analysis and Gramsci's theory of cultural hegemony to identify variations in the consolidation of official nationalism. ${ }^{4}$

For starters some conceptual clarifications are in order. This study draws on scholarship that conceives of nationalism as an ideology: a socially shared mental framework that supplies ways to imagine community, identify fundamental patterns of sameness and difference among people, make political claims, and organize social relations (Brubaker 2004; Calhoun 1997). ${ }^{5}$ Seen in this light, the basic underpinning of nationalism as an ideological form is the idea that the world is divided into nations, each authentic entities with their peculiar history and culture; that political loyalty is primarily structured around nations; and that nations are or ought to be self-governed (Gellner 1983).

We specifically focus on nationalism as an adaptable but explicit ideology advanced by states with the aim to legitimate their authority and achieve social control. ${ }^{6}$ State-sponsored national ideologies, even though similar in form, may vary in their ideological content, or how they conceive of the historical and cultural particularities of the national community and the criteria for national inclusion. ${ }^{7}$ In fact, the content of state-sponsored national ideologies can and does change, especially when shifts in ruling coalitions for the consolidation of state power occur (vom Hau 2008; Wimmer 2002). Reworking official representations of the nation may provide state leaders with an ideological tool to legitimate their rule and differentiate themselves from the previous regime. New ruling coalitions may also make state authorities more responsive to the demands of previously excluded actors - whether certain economic elites, subordinate classes, or certain ethnic groups - to redefine established conceptions of nationhood.

In this article, however, we sidestep the issue of why states might change the content of their official nationalism. Our main interest is in tracing variations in the consolidation of a new (or changed) state-orchestrated national ideology. States might attempt to impose particular understandings of nationhood, but the presence of these representations of the nation in public culture should not be taken as a given. This article thus seeks to uncover how new official conceptions of national identity and history are expressed and enacted in a broader set of images, discourses, and narratives found in the public sphere. We argue that shared mental frameworks such as nationalism require social resources (e.g., financial means, administrative capacities, mass literacy, communication networks) in order to be created, disseminated, and reproduced over time, and are therefore best studied not at the individual level, as subjective beliefs, but at the meso-level, as embedded in particular organizational settings (Wuthnow 1989b). Seen in this light, the consolidation of a new state-orchestrated national ideology does not come about through individual-to-individual conversion, but is best conceived as the result of the nation-work done by culture producers and their organizations.

\footnotetext{
${ }^{4}$ The scholarship on cultural hegemony is vast and often contradictory, not the least because Gramsci's journal notes do not provide a precise definition. We found Lears (1985) particularly helpful in clarifying the analytical and empirical implications of the concept.

${ }^{5}$ For a more general discussion of ideology as a shared mental framework see van Dijk (1998).

${ }^{6}$ Although these manifestations of nationalism are beyond the scope of this article, we are keenly aware that social movements and other civil society actors may employ counter-state nationalism in order to mobilize political support and challenge state authority (Breuilly 1982; Hobsbawm 1990). Similarly, state-sponsored national ideologies do not necessarily have much in common with the everyday understandings of nationhood held by ordinary people (Brubaker et al. 2006; Fox and Miller-Idriss 2008).

${ }^{7}$ For example, scholars often distinguish between civic and ethnic variants of nationalism (e.g., Greenfeld 1992; Smith 1986).
} 
In theorizing the consolidation of official nationalism, we draw on Gramsci's $(1971,259)$ insights that ideological change usually involves a combination of domination and hegemony - or the mobilization of consent. We therefore distinguish between two distinct processes that are involved in the consolidation of an official national ideology: (a) its state-led imposition and (b) its liberal circulation in the public sphere. ${ }^{8}$

States engage in various forms of "organized persuasion" (Gorski 2003) in order to inculcate new ideological contents among their populations. Of particular importance is the state cultural machinery - the organizational facilities and communicative networks directly dedicated to ideological production and circulation (Berezin 1991), most prominently the public school-system, but also civic festivals, museums, or archeological excavations. Across these different organizational contexts, the diffusion of a new national ideology becomes embedded in established routines, such as school curricula or national holiday celebrations, and is often carried out by professional cadres endowed with significant symbolic power (e.g., teachers or expert committees). The state cultural machinery also fosters particular ideological contents through its regulatory role in areas such as communications media and educational facilities, and the selective provision of resources (whether in the form of material support or access to broader audiences) to the producers of certain ideological objects (e.g., school textbooks or radio broadcasts) (see Wuthnow 1989a). Seen in this light, state organizations, by regularly interacting with and socializing citizens and systematically promoting certain ideological contents over others, are centrally involved in the direct imposition of a new official nationalism in public life.

At the same time, the consolidation of a new official national ideology, as more widely held public forms of nationalism, requires more than imposition. As Gramsci (1971) reminds us, hegemony involves the successful mobilization of "active consent" in society, and this does not depend on indoctrination and the regulation of ideological production alone, but also on some ideological contents becoming more widely accepted and thus readily available in the public sphere than others (Lears 1985, 577). Building on these insights, liberal circulation means that new state-sponsored representations of national identity and history appeal to a wider range of collective actors that engage in nation work. Thus, even culture producers situated outside the state's ideological machinery and/or who are not immediately dependent on state support, for example, commercial publishing houses, radio broadcasters, or film companies, disseminate the new state-sponsored conceptions of nationhood. There are a variety of plausible mechanisms that underpin liberal circulation. Culture producers might be drawn to a transformed state-sponsored nationalism because it opens up new avenues for artistic expression. They might also experience a new ideological framework as providing them with novel resources for "solving" practical challenges they face, including but not limited to making a living, maximizing profit, and/or gaining in status (see McDonnell et al. 2017).

\section{The Empirical Research Strategy}

Equipped with this conceptual framework we now turn to develop our empirical approach for investigating variations in the public consolidation of official nationalism. To do so, we will first discuss our choice of school textbooks as a source for tracing the state-led imposition of

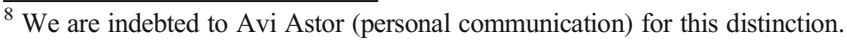


national ideologies, and picture postcards as visual artifacts for exploring their liberal circulation. This will be complemented by reflecting on our operationalization - the criteria we apply for empirically evaluating whether we indeed witness the consolidation of a new official nationalism in mid-twentieth-century Mexico, Peru, and Argentina.

\section{Textbooks and the State-Led Imposition of a New Official Nationalism}

There is little disagreement that mass schooling constitutes the nationalizing institution of the state. School curricula used in mass education are often taken as entry points to study the shared cultural references and collective identifications that states seek to instill among their populations (Weber 1976). We therefore follow an established scholarship that uses textbooks as sources to study the state-led imposition of official national ideologies (vom Hau 2009; Schissler and Soysal 2005). Although professional standards, broader pedagogical and philosophical discourses, as well as the views of the individual authors matter, state actors ultimately determine textbook contents. And even in contexts where textbooks compete as market commodities, the parameters of this competition are defined by state intervention, for example, in the form of textbook selection committees and special approval procedures. Hence, despite their appearance as authoritative accounts of the truth, textbooks, in fact, convey particular visions of social reality, codifying knowledge that is deemed as socially and politically appropriate. What further distinguishes textbooks as an especially valuable data source to explore the state-led imposition of official conceptions of nationhood is their substantial reach as books that are frequently printed in editions of several hundred if not millions of copies.

Yet, it is also clear that there is ample room for teachers, students, and the broader public sphere to interpret, rework, or outright reject textbook content dictated from the top (vom Hau 2009). More generally, we cannot assume that — despite the massive efforts of states - official representations of the nation automatically gain traction in the wider public sphere. While acknowledging that state-orchestrated conceptions of nationhood do not come from thin airthey are at least partly based on social, cultural, and historical building blocks (Smith 1986) the extent of their liberal circulation is an empirical question and requires another analytical window.

\section{Postcards and the Liberal Circulation of a New Official Nationalism}

In order to investigate the liberal circulation of new (or changed) official national ideologies, we exit the realm of education and contrast our findings from schoolbooks with notions of nationhood as depicted on picture postcards. In combination with textbooks, the latter constitute an unconventional and novel source of data for the study of nationalism. ${ }^{9}$ As Semmerling $(2004,1)$ notes, postcards, like novels and newspapers, are part of print capitalism and foster identification with the nation as an "imagined community" (Anderson 2006[1983]). Having emerged in the nineteenth century in Central Europe as a result of advances in print technology and photographic image-making, picture postcards became the most prominent visual mass medium in the world during the late nineteenth and early twentieth century, in their so-called

\footnotetext{
${ }^{9}$ Some studies rely on postcards to study nationalism (e.g., Semmerling 2004; Onken 2014), while other scholarship traces dominant understandings of nationhood by investigating the broader visual culture (e.g., Mraz 2009; Giordano 2009).
} 
“Golden Age" (Onken 2016). While beforehand works of art or photography were expensive to reproduce and therefore beyond the means of many ordinary citizens, now images could, for the first time, be consumed regularly by various audiences, including middle sectors, the lower classes, and - especially from the 1950s onwards - tourists from abroad (Mraz 2009, 2-3). In fact, during the time period of our study, a large number of people came into contact with postcards as relatively cheap and widely available cultural objects that did not require the consumer to be literate. ${ }^{10}$

Similar to textbooks, picture postcards represent and thus construct particular understandings of national identity and history. This is because the formal characteristics of postcards are explicitly national; the name of the state is often inscribed on the postcard, which also bears the stamps and the cancellation marks of the national postal system when sent by mail. Moreover, postcards serve a ubiquitous nationalist aspiration to project a unique identity and authentic culture to the world (Semmerling 2004). Finally, while textbooks' credibility stems from the authority vested in the institution of education, postcards are rendered credible via the "truth value" assigned to the medium of photography itself, believed to be a window into reality (Mraz 2009, 3).

Postcards, as visual artefacts primarily created for commercial purposes, are on constant public display and routinely signal particular understandings of nationhood across the national territory. However, it is not state officials who shape the representations of the nation conveyed by postcards, but private entrepreneurs in search of profit. While the producers of picture postcards receive and interpret the official national ideology from a specific class position, they are also cultural entrepreneurs; as such, they seek to cater postcard images to what they perceive as the currently dominant understandings of nationhood that prevail in public life.

\section{Evaluating the Consolidation of a New Official Nationalism}

The issue that remains to be addressed is the following: What would indicate to us empirically that we are seeing ideological consolidation? How do we know that new (or changed) official representations of the nation infuse a broader set of images and narratives found in the public sphere?

In a first step, we will trace representations of national identity and history found in school textbooks at different points in time in each country. Empirical support for state-led imposition comes from observing that a new national ideology is not confined to government speeches and party manifestos anymore, but also becomes part of regular ideological production by states, as indicated by changes in textbook contents. Moreover, we compare textbooks to postcards and treat the resemblance of ideological contents found in these two sources as indicative of liberal circulation. In other words, the prevalence of popular-assimilationist understandings of nationhood in both school textbooks and picture postcards provides initial evidence for the expression of this new national ideology in public culture more broadly in mid-twentieth-century Mexico, Peru, and Argentina. By contrast, stark differences between representations of the nation found in textbooks and postcard images suggest a limited consolidation of a transformed state-sponsored national ideology.

To crosscheck and validate the insights derived from the content analysis of textbooks and postcards we also consult the available secondary evidence on postcard production in late

\footnotetext{
${ }^{10}$ This stands in contrast to other material manifestations of nationalism, for example, those found in high art, museum exhibits, or architecture.
} 
nineteenth- to mid-twentieth-century Latin America. This article is specifically concerned with evaluating relevant information on how the commercial printing and dissemination of picture postcards unfolded and how the relationship between postcard producers and (the cultural machinery of) the state evolved over time. In doing so, our historical analysis also seeks to unearth - as much as is possible, given historical data constraints - the motivations of postcard publishers to disseminate particular understandings of nationhood. We treat the relative absence of explicit state sanctions and/or regulations in the domain of postcard production as evidence in support of liberal circulation. This is because under those conditions it is safe to assume that postcard producers were not coerced or "regulated" into disseminating the new popular-assimilationist nationalism.

Beyond the congruence between textbooks and postcards and the conditions of postcard production, we also draw on between-country comparisons to assess the extent of ideological consolidation in the three countries. For one thing, comparing representations of the nation in Mexico, Peru, and Argentina allows us to move beyond country-specific idiosyncrasies and explore analytically relevant ideological contents of nationalism (e.g., liberal-elitist vs. popular-assimilationist) across countries, sources, and time periods. The comparison between these Latin American countries further allows us to identify more clearly the empirical instances that are in sync with our conceptual framework. Most prominently, ideological consolidation is taking place if temporally congruent changes in understandings of nationhood found in textbooks and postcards can be identified for more than one of the three countries. By contrast, if we find that the timing of changes in textbook and postcard contents varied randomly across the three countries, then we might be witnessing ideological continuity or a different process of ideological change not captured by our conceptual approach.

\section{Data Collection and Sampling}

In order to evaluate variations in the consolidation of new official national ideologies in Mexico, Peru, and Argentina, we examine school textbooks in the historical period when state leaders started to advance popular, class-based conceptions of national identity and history. The exact moment in time varied by country, and we therefore concentrated on postrevolutionary Mexico during the 1930s and 1940s, Peronist Argentina during 1940s and 1950s, and Peru during the 1960s and 1970s. For the textbook analysis we used 34 civic education, history, and general primary education texts. ${ }^{11} \mathrm{We}$ then proceeded to thematically analyze the postcard material. Specifically, we manually coded a sample of 600 postcards selected from an image bank containing over 3500 unique postcards published in the three countries between 1890 and 1980. While the analytical window of our paper is the midtwentieth century, we have also included postcard images from a prior time period (the 1900s and 1910s) in order to better contextualize our findings.

For the textbook analysis, we sought to review at least five representative texts per decade. To select them from the wider pool of textbooks available in national libraries and special collections we consulted in Mexico, Peru, and Argentina, ${ }^{12}$ we employed three main criteria: First, we focused on primary school textbooks because only a small segment of the population

\footnotetext{
${ }^{11}$ Our textbook analysis draws on a larger project that traces changes and continuities in official national ideologies in nineteenth- and twentieth-century Mexico, Peru, and Argentina based on more than 200 texts (e.g., vom Hau 2009, 2015).

${ }^{12}$ While the number of textbooks available at these sites was sizeable, it is hard to establish exactly how many textbooks were published in any given year and how many of them ultimately remain available for consultation.
} 
attended secondary schools during the time period of interest. Second, we selected those texts that were published or approved by national educational authorities. Third, we preferred approved texts that were reprinted in several editions, indicating their actual use.

For picture postcards there is no way of knowing exactly how many cards were published and how many survived from the historical period of interest. Our strategy was therefore to use the Internet for gathering as many postcards as possible, mainly from online auction sites, the largest ones being eBay (https://www.ebay.com/), Marcelo Loeb Postcards (www. marceloloebpostcards.com), and Hippostcard (https://www.hippostcard.com/) in order to build an image bank. The postcards included in it certainly do not constitute a representative sample. However, we believe that there are certain advantages to our auction site-based data collection strategy. For one thing, the majority of the postcards sold by these auction sites can reasonably be assumed to have been produced in large enough quantities and/or have remained in circulation for an extended period of time in order to survive until this day, and are therefore indicative of liberal circulation. Moreover, there are also more specific advantages when comparing our auction sites to postcard collections available in archives and libraries. On the one hand, collections that do have regional or even global coverage (and therefore cover all three countries) tend to be skewed towards certain themes, styles, or historical periods. For example, we consulted the Gilles Gagnon Postcard Collection held by the Canadian Centre for Architecture in Montreal, which includes about 11,000 cards from over 190 countries, but found that it only starts in 1950 and is too focused on postcard images depicting architecture and landscape. On the other hand, "comprehensive" postcard collections that cover many themes over long periods of time tend to be country-specific. We initially worked with the outstanding Mexican Postcards Collection, which is held by Princeton University Library and includes more than 3000 items dating from 1890 to 2000, but we were unable to unearth comparable collections for Argentina and Peru.

When gathering postcards from auction sites, we employed simple keyword searches (e.g., "Argentina postcard 1940") and/or manually browsed through the material on offer. We only selected images for which we had information regarding the year/decade they were published, and we filtered out images that were of little relevance to our study (e.g., postcards depicting flower compositions, actors, or fashion models; images that were very abstract or artistic; and pictures serving as promotional material for private enterprises and products). We also excluded postcards that could be directly tied to the state, that is, those issued by tourist associations or other agencies. ${ }^{13}$ Finally, we eliminated images that were obviously printed abroad and clearly targeted foreigners (e.g., postcards that had English-language explanatory notes printed on them). Some postcards came up multiple times, but we downloaded every image only once.

It bears emphasis that our image bank is not balanced. The number of postcards we were able to gather varied across time and country. For example, we found more postcards from Mexico than from Peru or Argentina. In order to balance out our data and also make our analysis more manageable, we relied on a combination of stratified and random sampling. Namely, we randomly selected 50 postcards per country for every decade of analysis (1900s and 1910s for all three countries, 1930s and 1940s for Mexico, 1940s-1950s for Argentina, and 1960s-1970s for Peru), and then proceeded to manually code the resulting 600 images. The two-decade timespan is also meant to capture possible time lag between the ideological

\footnotetext{
${ }^{13}$ The proportion of such postcards was actually very low-less than $10 \%$, providing further evidence that postcard production in mid-twentieth-century Latin America was predominantly market-driven.
} 
transformation of official nationalism (as indicated by textbook contents) and changes in the publication of postcards.

\section{Coding and Interpretation}

Examining meanings produced in different sites and with different tools calls for a careful alignment of the collected material. In practice, this entails operationalizing the basic conceptual elements of national ideology in a manner that renders them detectable and comparable across various domains and expressive repertoires, visual and textual. With these considerations in mind, we identified a number of dimensions that we believe meaningfully capture variations in understandings of nationhood across textbooks and postcards. More specifically, we explored how major historical epochs were portrayed, who appeared to be the main protagonists of national history, and what their respective class position, wealth, and ethnicity were. We also investigated whom textbooks and postcards represented as national heroes and who emerged as a major enemy to the nation. Finally, we focused on who appeared to embody the national community (i.e., national archetypes) and their social and ethno-racial background, and how hierarchies of national belonging were established, for example, by tracing characterizations of immigrants and indigenous people.

At this point we should note that the analysis of images requires more inference than other forms of data (Grady 2008). We have sought to mitigate this ambivalence by quantifying our observations derived from the postcards while simultaneously relying on in-depth knowledge of the three countries and close familiarity with the specific historical contexts we are dealing with. We also used a double-coding strategy, with both authors first reviewing a subset of the selected postcards separately, and then conciliating instances of disagreement together. ${ }^{14}$

For the visual analysis, we further broke down our coding scheme and categorized each postcard along four dimensions, which were specifically tailored to capture variations of nationhood: heritage, wealth, activity, and ethnic background. ${ }^{15}$

Heritage Many postcards do not foreground people (individuals or groups) but particular objects (e.g., ships, cars, buildings) and places (e.g., streets, cities, mountains, beaches). In so doing, these postcards reveal claims to "national uniqueness" and emphasize the technological, architectural, and/or cultural achievements of particular periods. The heritage category therefore focuses on immobile/non-human motifs and situates them in major epochs of national history. Specifically, we distinguish between motifs from (a) recent/modern history, (b) the colonial period (including Christianity with which it overlaps), or (c) the ancient/indigenous past.

Wealth Indicators of wealth are an important identifier of how the "nation" is imagined and who is considered an integral part of the national community. We distinguish between (a) high, (b) medium, or (c) low levels of affluence, based on the content of the postcards: for example,

\footnotetext{
${ }^{14}$ We independently reviewed 45 postcards randomly selected for testing intercoder reliability. The rate of agreement was $80 \%$. We then discussed the disputed items, thereby further clarifying and refining our coding criteria, in the end reaching an almost complete agreement.

${ }^{15}$ When it was not possible to code a picture postcard along one or more dimensions (for example, it was showing a person in a close-up with no reference to their material surroundings), we coded this element as "missing." Finally, for each coding category we created an "other/mixed" set, to which we relegated all elements that could not be categorized with certainty (approximately $10 \%$ for each). These were subsequently excluded from the visualizations for the sake of clarity.
} 
the size and sophistication of buildings, the roads (e.g., dirt road versus paved road), vehicles (autos or animals), the attire and accessories of people, and the display of amenities such as electricity and potable water are indicative of wealth levels. Sometimes we also took stylistic elements into account, such as the coloration and composition of a picture.

Profession/Activity When individuals were present on postcards, we coded the activity in which they were engaged and indications about their professional status more broadly. Of particular interest was whether the persons we encountered were (a) passive bystanders to an event or an inanimate object, or whether they were shown as being involved in an activity. We further unpacked the latter by distinguishing whether those active individuals (b) were engaged in some form labor, whether manual or not; (c) participated in religious ceremonies or other non-religious festivities (e.g., national holidays); or (d) were involved in activities associated with military or political leadership (e.g., riding a horse in full military uniform or giving a speech).

Ethnicity This coding category only applies to pictures that foreground individuals. The distinction between (a) indigenous, (b) mixed/multiple, and (c) European/white was based on the particular ethnic and racial markers of people emphasized by postcard images, including, among others, dress codes, cultural practices, or phenotype. When these markers were not easily discernible (e.g., because individuals were too far away) our preference was to err on the side of caution and, therefore, to leave this dimension blank. Further, we defined the parameters of the mixed/multiple category rather broadly, to include either individuals who could be classified as mestizos or the co-presence of people from different ethnic backgrounds. ${ }^{16}$

As the next sections will discuss in greater detail, the resulting frequency counts help to identify major similarities and differences in public understandings of nationhood. High scores in depictions of European cultural heritage, affluence, political and military elites, and whiteness indicate the prevalence of a liberal-elitist version of nationalism. Conversely, the predominance of representations of ancient heritage, indigenous and/ or mixed ethno-racial background, depictions of common people, and less emphasis on material wealth point to a popular-assimilationist version of nationalism. In order to give more interpretive depth to the frequency counts, and to take into account both the content of the postcards and the modes of visual expression, we also use compositional interpretation (Rose 2001, Chapter 2) for a small number of images. While the relative presence or absence of a particular element from postcard images, for example, a population category or historical epoch, constitutes an important piece of information, it remains somewhat incomplete. For example, the omission of subordinate classes from postcards may reasonably be taken to signal their exclusion from prevailing conceptions of the national community. However, it is often the case that these populations are, in fact, made visible but portrayed in degrading or highly stereotypical ways. The broader methodological point is that frequency counts are indicative of a general pattern and ideally need to be complemented by contextsensitive in-depth analysis.

\footnotetext{
${ }^{16}$ For the sake of simplicity, we do not code separately the various indigenous populations, which were of course far from uniform. We also do not include an Afrodescendant category, since this was practically nonexistent in our image bank.
} 


\section{The State-Led Imposition of Nationalism in Textbooks ${ }^{17}$}

Even though Mexico, Peru, and Argentina varied dramatically with respect to their colonial history, struggles for national independence, and their postcolonial political development, in all three of these Latin American countries state leaders embraced liberal-elitist nationalism ${ }^{18}$ as official national ideology during the late nineteenth century. Textbooks from this timeperiod represented the nation as a political association, grounded in a social contract among citizens that was symbolized by a shared constitutional framework. In all three countries, official history was organized around the emergence of a binding legal and political order, while the conflicts between central state elites and regional strongmen that characterized the early nineteenth century were largely absent from these accounts.

This political-territorial understanding of the national community converged with the idea of creating a "civilized nation," a category associated with whiteness, economic modernization, and an urban and cosmopolitan European culture. This is powerfully shown by the overall assessment of Spanish colonialism found in textbooks: "Once the blood and the tears dried up and the pain was forgotten, [...] the slow and efficient work of a more advanced civilization began, constructing on top of the old one a new society...the Mexican nation" (Torres Quintero 1913, 75). And this "civilizing" process was driven by benevolent and enlightened elites. "Without the boldness of Hernán Cortés [the Spanish conqueror of the Aztec empire] the country would have never been conquered and submitted under Spanish government" (Lainé 1890, 3). Thus, seen through the lens of school textbooks, late nineteenthand early twentieth-century state-sponsored conceptions of nationhood fused Enlightenment ideals of political citizenship with highly exclusionary and hierarchical visions of the national community.

During the mid-twentieth century, Latin American countries witnessed state consolidation, rapid economic growth, industrialization, and urbanization. These modernizing trends were closely entwined with the rise of mass politics and instigated claims to redefine dominant understandings of nationhood. New ruling coalitions with mobilized middle-class segments and subordinate sectors propelled the populist governments of Lázaro Cárdenas (1934-1940) in Mexico, Juan Domingo Perón (1946-1955) in Argentina, and Juan Velasco Alvarado (1968-1975) in Peru to adopt popular-assimilationist nationalism as their official national ideology. State-approved textbooks are indicative of this change. The texts published under these governments were strikingly similar in that they promoted cultural and class-based understandings of nationhood, celebrating "the people" as authentic nationals.

\section{Textbook Versions of the Nation in Mexico}

In Mexico, the Revolution (1910-1920) ended decades of oligarchic rule and entailed the political and symbolic incorporation of subordinate sectors. Under Cárdenas, the government devised a new curriculum and selected new history and civics textbooks (Vaughan 1997). These books advanced a definition of Mexican society as a mestizo nation made up of workers, peasants, and smallholders. Mestizaje, the process of racial and cultural mixing

\footnotetext{
${ }^{17}$ This section builds on a more detailed textbook analysis (vom Hau 2009, 2015). The Online Appendix includes the complete list of texts specifically used for the content analysis presented in this article.

${ }^{18}$ The term liberal nationalism has a specific meaning in the Latin American context and is widely used in the relevant historiography on the late nineteenth century (Eastwood 2004).
} 
between Spanish colonizers and indigenous peoples, replaced whiteness and the spread of "civilization" as the legitimate mechanism of integrating the national community. Even though people of indigenous, African, and Asian descent could - in theory-be assimilated into mestizo Mexicans, racial hierarchies persisted, with the eventual endpoint being a predominantly urban, Spanish-speaking, whitened population.

This said, the Mexican mestizo nation was presented as predominantly working class. People of humble origin, manual workers, and peasants as well as the middle sectors populated the texts. These classes were also granted agency: "Against the orders of Montezuma, the masses rose up and launched a massive attack against the Spanish" (de la Cerda 1943, 131). By contrast, political elites were cast in a less sympathetic light: "Hernán Cortés did not have much talent and abandoned his studies to pass his time on the street" (Castro Cancio 1935, 44). It was also "the people" who rose up against the Porfiriato. One textbook, for example, explains the Mexican Revolution as "a revolution of the exploited poor against the opulent exploiters" (Castro Cancio 1935, 250). As this text also shows, the most relevant social distinction transcending centuries of Mexican history was that between the "people" and the "oligarchy." What the "nobility," composed of "priests and warriors" in the Aztec Empire (Orozco 1938, 103, 113), and the merchants and large landowners of the colonial period (Cancio 1935, 105) shared was their exclusionary and exploitative ways. Spanish colonialism, in particular, was cast as cruel and greedy foreign domination. The spiritual and material heritage of the nation was decidedly pre-colonial. Textbooks equated contemporary Mexico with the Aztec empire, a connection established also by the practice of depicting ordinary Aztecs as Mexicans.

\section{Textbook Versions of the Nation in Peru}

In Peru, oligarchic power persisted much longer, and it was only the leftist military government of Velasco that attempted the political incorporation of popular classes through a corporatist framework. The new generation of textbooks adopted by the military rulers spoke of "workers, peasants, and the middle sectors" as the core of the national community (Fichas 1974b, 5.5), while visual representations focused on children whose parents worked as carpenters, farmers, or small shopkeepers (e.g., Amigo 1976; Paseo 1976). Indigenous peoples, hitherto blamed for the persisting cultural and racial divisions in Peruvian society, were now integrated into the nation based on their class position as peasants and workers. For the first time, textbooks presented them as productive contributors to the nation instead of obstacles to national progress. Like in Mexico, here too, the most important axis of division was between "the people" and the oligarchs (Fichas 1974a, 3, 31.4; 1974b, 5.3). The texts marked the latter as not fully belonging to the nation, for example, by stating that "Peruvian capitalists" and "large landowners" solely wished to "enrich themselves" and therefore invested their profits abroad (Fichas de Ciencias Sociales 1974a, 5.3, 16.2; 1974b, 31.4; Venciendo 1976, 128-129).

Spanish colonial rule was presented as a period of foreign domination. With its focus on modernization and urbanization (especially of Peru's coastal regions), colonialism, it was argued, had distorted Peruvian identity, which was now cast as predominantly rural and Andean. Pre-Columbian heritage was elevated to the status of authentic national culture, while the origins of the Peruvian nation-state were projected back to the Inca Empire: "A long time ago Peru was governed by kings called the Incas. Peru was then called the Inca Empire" (Peruanito 1974, 27). Like in Mexico, textbooks cast the people as the protagonists of history. "Peruvians always fought against the Spanish" (Fichas 1974a, 31.3) and "rose up against the abuse colonial authorities committed against indigenous people" (Venciendo 1976, 111). 


\section{Textbook Versions of the Nation in Argentina}

In Argentina, the highly personalistic movement of Juan Domingo Perón brought about the political and symbolic incorporation of subordinate sectors. During his government, the school curriculum went through a drastic overhaul. In Peronist textbooks, manual workers-for example, carpenters and mechanics-emerged as the authentic representatives of the Argentine nation (de García 1954, 17) and replaced the upper classes as the protagonists of national history. For example, it was " $[\mathrm{t}] \mathrm{he}$ worker [who] employs his strength to construct a great Argentina" (de Palacio 1952, 41). Accordingly, the independence wars succeeded not because of enlightened leadership, but because of the actions of "[b]rave and heroic gauchos [who] strolled around the mountains and caused despair among the hostile troops with their surprising attacks" (de García 1954, 85). Breaking with earlier texts that focused on the individual genius and bravery of political and military leaders, Peronist textbooks now stressed their proximity to ordinary people, for example, by depicting San Martín as "a man of the people" (de Palacio 1952, 124) or stressing the "humble origins" of Sarmiento (de Palacio 1952, 124, 108). Similarly, Juan and Eva Perón were cast as benevolent leaders of the masses, who had a profound understanding of ordinary people.

In terms of ethnic diversity, textbooks depicted migration to Argentina in generally favorable terms. These descriptions focused almost exclusively on migrants of European descent, propagating the idea of a predominantly white and European Argentina as the endresult of the crisol de razas, or the local version of the melting pot. "Blond and brown kids, Italians with blue eyes and Spaniards with dark hair, men and women from all parts come to Argentina, in the hope of [finding] a world of peace and calm, where the dignity of work is respected" (de García 1954, 164). Such textbook descriptions were in line with the general Peronist stance that stifled ethnic and cultural diversity and recognized social class as the only relevant source of social segmentation and political representation (Adamovsky 2016, 157).

In sum, textbooks published in mid-twentieth-century Mexico, Peru, and Argentina illustrate the state-led imposition of the new popular-assimilationist nationalism. To assess its liberal circulation, we now turn to the analysis of picture postcards.

\section{The Liberal Circulation of Official Nationalism in Postcards}

Since the late nineteenth century, postcards have been commercially produced and disseminated in Latin America. Most of the early postcard production was in the hands of first- or second-generation European immigrants, who settled in the urban centers of Mexico, Peru, and Argentina, whereas during the mid-twentieth century, the commercial producers of postcards came from many different backgrounds (Onken 2014).

In Mexico, the first postcard stationary was commissioned by the government of Porfirio Díaz. As demand for postcards soared, creating a new market, a greater number of producers got involved, including large companies enjoying official sponsorship (such as the Sonora News Co., which was allowed to sell printed material at railway stations), but also smaller independent enterprises (Guevara Escobar 2015). Once the market was established, the initial impulse of the Porfirian state to get postcards with official ideological messages produced gave way to private entrepreneurship, with up to 150 businesses engaged in the production of Mexican postcards by the 1910s. In Argentina the first series of postcards was published by the General Direction of Mail and Telegraphs in 1897 using images of the Sociedad Fotográfica 

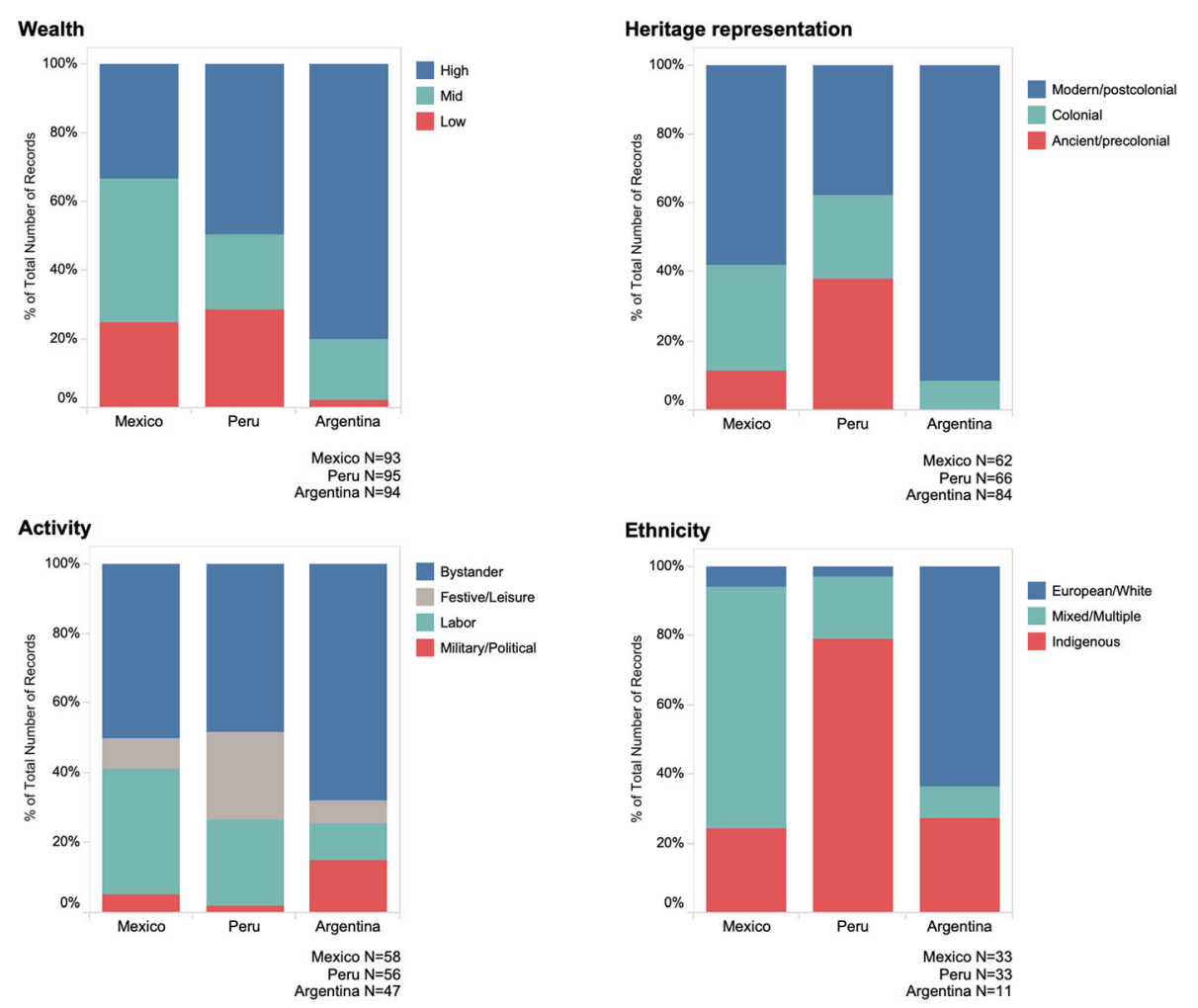

Fig. 1 Postcard content, Mexico 1930s-1940s, Peru 1960s-1970s, and Argentina 1940s-1950s

Argentina de Aficionados (Alexander and Priamo 2017, 245). The field expanded rapidly and remained in the hands of private businesspeople. In Peru, a central figure of early postcard production was Max T. Vargas, an Arequipa-born photographer who not only was a talented artist but also "had an entrepreneurial flair and a keen eye for trends" (Buchholz 2015, 128). Martín Chambi, a world-famous Peruvian photographer and perhaps the only person of indigenous background whose photographs became widely circulated as postcards (Onken 2016), initially apprenticed in Vargas's studio, subsequently setting up his own studio in Cuzco during the 1920s (Buchholz 2015). In all three countries, photographers often sold their material in their own studios and beyond, but it was also common for prominent postcard businesses, such as the Mexico City-based Compañia México Fotográfico, which operated from the 1920 s to the 1970 s, to hire their own photographers and send them on missions to various locations across the country (Jolly 2018, 41).

Postcards were used by locals to exchange messages with friends and family. But the public presence of postcards was not limited to those households whose members could read and write, as they could be used simply as decorations. Other frequent consumers of postcards were European and North American tourists, who sent postcards home to friends and relatives or bought them as souvenirs (Onken 2016). Postcards also became collectible items, which is why many surviving items have never been postally used. And although most postcards were published and sold in cities, given their mass production and postal function, they dispersed across national space, wherever shops of publishers or photographers and libraries existed (Onken 2016). 


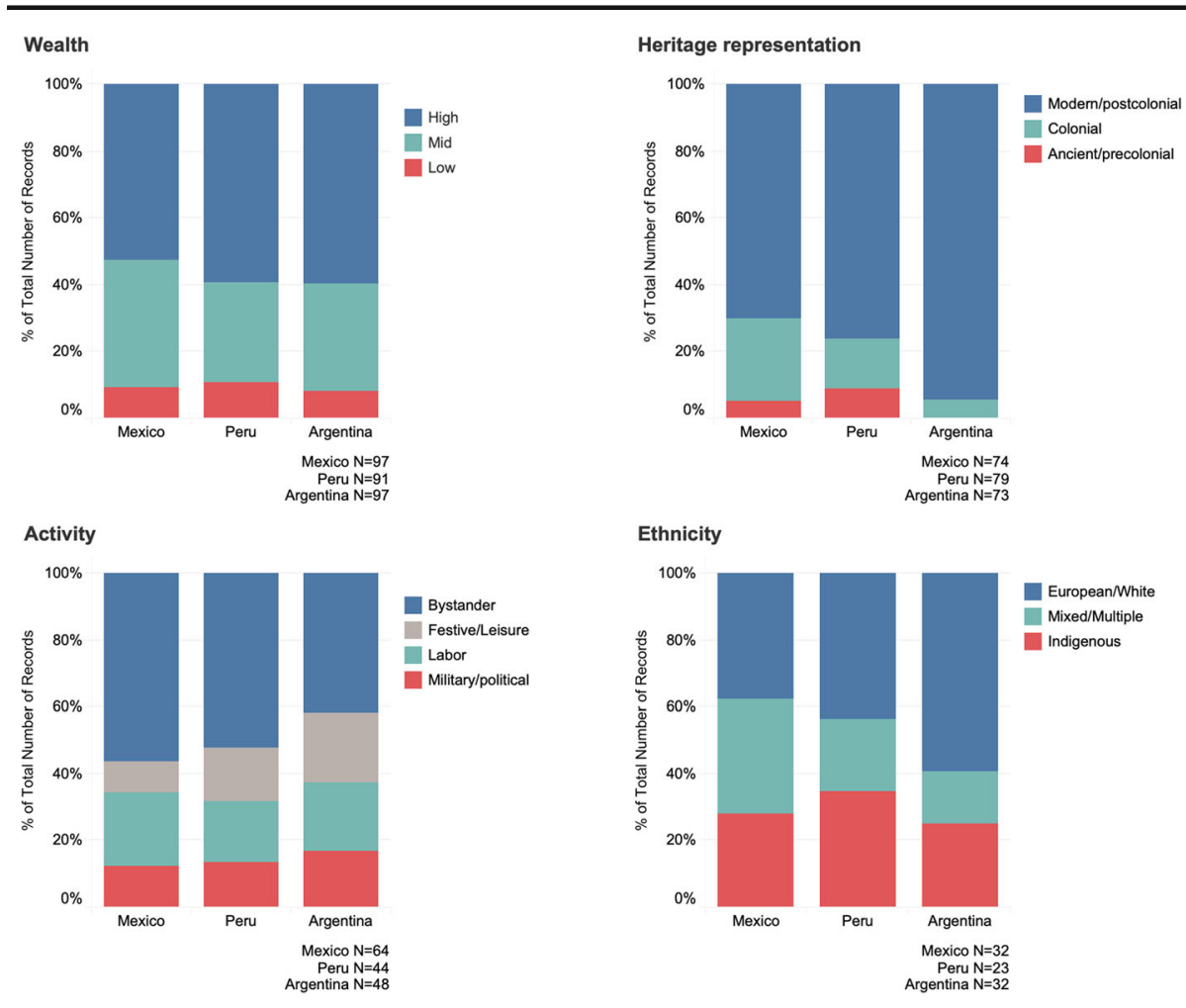

Fig. 2 Postcard content, Mexico, Peru, and Argentina 1900s-1910s

Our examination of postcards attests to differences in the liberal circulation of the new official nationalism promoted by textbooks across the three countries. Fig. 1 summarizes the results of the content analysis along four dimensions: wealth, heritage representations, the types of activity depicted people engage in, and their ethno-racial background. With some variations (to be unpacked below), the dominant markers of nationhood in Mexican and Peruvian postcards are illustrative of popular-assimilationist nationalism: low- and mid-level indicators of wealth combined with considerable attention paid to ancient heritage, along with a strong emphasis on common people, often of mixed and/or indigenous backgrounds. In Argentina, conversely, the postcards reveal liberal-elitist nationalism: markers of wealth and high social class combine with an emphasis on European modernity and whiteness. The overall picture is unambiguous: while the changing representations of the nation found in textbooks and postcards are broadly congruent in mid-twentieth-century Mexico and Peru, this is clearly not the case in Argentina, where understandings of national identity and history found in textbooks were markedly distinct from those we encountered in postcards.

This finding is even more striking when bringing a historical perspective to bear. As shown in Fig. 2, during the 1900s and 1910s, textbooks and postcards are indicative of liberal-elitist nationalism in the three countries. ${ }^{19}$ Visually the ideal of creating a "civilized nation" was

\footnotetext{
${ }^{19}$ Note, however, that resemblances are also in part explained by the novelty of the medium of postcards in Latin America, with photographers and editors often following European models.
} 
expressed through an emphasis on material wealth, industrialization, modernization, and urbanization. When early twentieth-century postcards foreground people, these are almost exclusively military or political leaders as well as the upper class, while representations of lower-class and/or indigenous populations tended to be distanced and even degrading. Clearly, postcards would continue to depict major cities and their publics, imposing buildings housing state institutions, iconic monuments, and statues of historical figures; nonetheless, the relative frequency of these themes as well as the modes of representation and expression diverge significantly over time, reflecting the consolidation (or lack thereof) of the new popularassimilationist nationalism in the three countries.

\section{The Nation on Mexican Postcards}

Postcards published in Mexico during the 1930s and 1940s communicate the same popular understanding of nationhood as school textbooks: they represent Mexico as a mestizo nation of peasants and workers.

As Fig. 1 shows, as many as two-thirds of the postcards, both those foregrounding people and inanimate objects, are on the lower end of the wealth distribution. Specifically, postcards focused on inanimate objects are not limited to the representation of prosperous urban areas with imposing avenues and buildings, even though these are a major theme. A large percentage of postcards from this period typically depict humble dwellings located in the countryside or smaller urban settlements. Other dominant motifs are markets and workshops, also sites that are not necessarily linked to affluence.

In postcard representations of built heritage, both the colonial and the precolonial period gain in weight. When compared to the early twentieth century, a larger proportion of postcards foreground colonial-era political buildings, churches, and other religious sites. Similarly, an increasing percentage of postcards shows images of Aztec and other precolonial sites, a pattern that signals a broader turn towards the rediscovery of Mexico's ancient roots. In fact, picture postcards, just like textbooks from that period, seek to establish the notion of historical continuity between the Aztec empire and the modern Mexican nation. For example, a frequent motif found on postcards from the 1930s and 1940s are portrayals of peasants working their fields or craftsmen selling their work, and a set of imposing pyramids filling up the image background.

Postcards that foreground people are equally not limited to elites but cut across socioeconomic status groups. When we get a closer look of Mexicans, this is typically as they engage in some kind of productive activity: agricultural labor, crafts and arts, and services, from hauling to cooking to laundry. While in the early twentieth century postcards depicted such workers in stereotypical, othering, and undignified ways, during the 1930s and 1940s, working-class Mexicans are portrayed with integrity and are even idealized..$^{20}$ This is especially the case in artistic representations-among them, reproductions of Diego Rivera's famous murals, but also pieces of less known artists. As exemplified by the postcard shown in Fig. 3, not only do peasants and workers become an important creative topic, postcards also seek to elicit sympathy and compassion for their subjects through their aesthetics, for example, by using warm colors and opting for harmonious compositions, which are meant to underline the simple

\footnotetext{
${ }^{20}$ Picture postcards of Mexican "types" that showcase lower-class people in traditional occupations, typically of mixed or indigenous background, predate the 1930s and 1940s (Osorio 2007; Rodríguez-Bravo and RiveraSánchez 2017). But on these older postcards rigid poses and the often exaggerated artificial coloration served as distancing devices, casting the protagonists as objects of either curiosity or pity.
} 
Fig. 3 No title. Editor: Federico

Liebig (circa 1940). Source:

Authors' collection

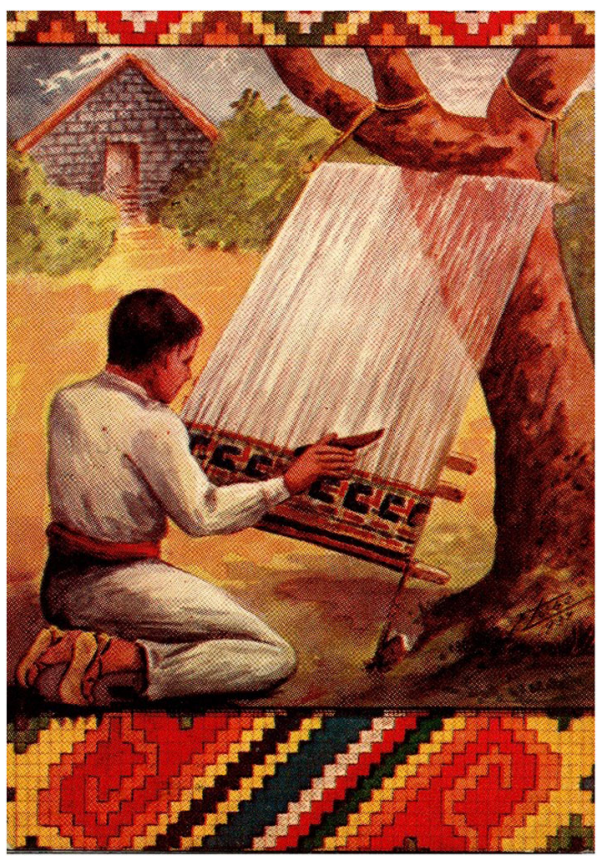

but honorable lifestyle of popular sectors. Such depictions correspond to the representations found in textbooks, which posit the centrality of "the people" as the authentic representatives of the Mexican nation.

A similar pattern can be detected in the way Mexico's ethnic composition is depicted. People on postcards published during the 1930s and 1940s appear predominantly as mestizos. That said, ethnicity and culture are rarely marked off as relevant identity categories, but are subordinated to the basic distinction founded on social class and professional status. On the one hand, this signaled the inclusion of nonwhite individuals in the national imagery; on the other, it also implied that the preservation of indigenous culture was not a desirable objective, and that ethno-racial differences within the mestizo nation were therefore largely irrelevant.

Fig. 4 Cuernavaca, Morelos, Manufacturer: Kodak Mexicana Ltd., n.d. (circa 1940s) Source: Authors' collection

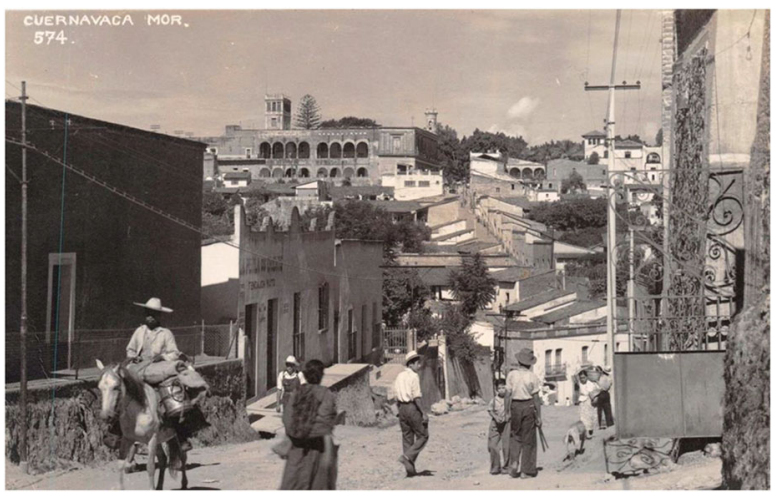


The typical places where people of different genders, ages, and ethnicities mingle as they go about their daily work are urban and suburban settings. A good example can be seen in Fig. 4, a postcard depicting Cuernavaca, the capital of the state of Morelos. The most important sight of the city, the Palace of Hernán Cortés, the Spanish leader of the military conquest of the Aztec empire, is relegated to the background. It serves only as the backdrop of what constitutes the real focus of the picture: a busy road. It is not the grand edifice that matters, but the women, men, and children who live around it. It would have certainly been possible to foreground the imposing buildings of the city, automobiles, broad roads, and gardens, with the urban middle and high classes strolling around. Yet, what we see is a smaller, unpaved street, where a donkey is the most advanced means of transportation and where people are going about their daily activities. In fact, the picture does not focus on one particular person, but on the collective, captured spontaneously. This unmarkedness and taken-for-grantedness signals a vision of Mexico as a nation of popular sectors who are actively pursuing their livelihoods and whose situation is shaped but certainly not determined by the legacies of Spanish colonialism.

\section{The Nation on Peruvian Postcards}

Similar to textbooks, Peruvian postcards from the 1960s and 1970s envision a nation of popular sectors that is endowed with a glorious precolonial past. Yet, in contrast to Mexico, postcards in Peru are less concerned with defining the national community as the product of mestizaje and more focused on the indigenous roots of national culture. Peruvian postcards also put less emphasis on the specific class identity of the nation (i.e., peasants and workers) than their Mexican counterparts.

As Fig. 5 shows, postcards departed from almost exclusively focusing on the affluence and modern urbanity of Lima. Approximately half of the pictures we analyzed focus on the more modest surroundings of Peruvians in smaller cities or in the countryside. Moreover, in terms of the major architectural, cultural, and technological achievements showcased, postcard images are almost evenly split between modernity and a regenerated antiquity: iconic archeological sites, such as Machu Pichu, the "Sacred Valley," and Cuzco city, attest to the identity of Peru as heir and Peruvians as direct descendants of one of the world's ancient civilizations: the Inca Empire. This is in tune with the content of the school textbooks examined beforehand.

The persons depicted on postcards published in mid-twentieth-century Peru are typically children, women, and men who mingle at markets, processions, and festivals. While they are

Fig. 5 Escena tipica de Mercado, Market Scene in Cusco. Foto Gorbacho, dated: 1975. Source: Authors' collection

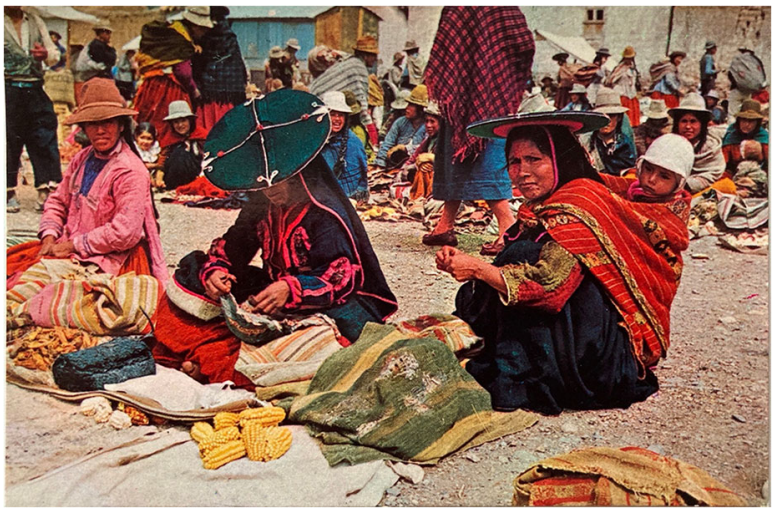


Fig. 6 Inti Raymi, Fiesta del Sol Cusco - Peru, Foto: Teo Allain Chambi 1975, Allain Chambi Producciones. Source: Authors' collection

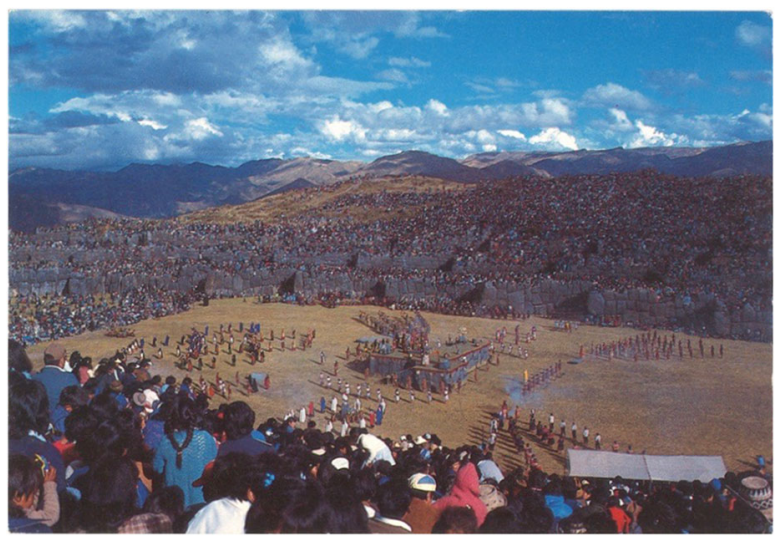

certainly not represented as being an elite or affluent, their social class remains somewhat ambivalent and is not explicitly linked to the status of either peasant or worker. But pictures and photographs tend to emphasize their indigeneity, usually by highlighting their skin color and facial features, and most importantly the kind of attire they wear (e.g., ponchos, chullos, sandals). In contrast to Mexico, there are fewer postcards of Peruvians engaging in activities such as farming, fishing, handicraft production, or industrial work. As shown on the postcard displayed in Fig. 5, what we did frequently encounter were images of one or more vendors, often women with children, selling their produce in marketplaces.

Another regular postcard motif were dancers and musicians attending festivities. They are usually portrayed on roadsides or mountaintops, or at sites of mass celebrations, such as the Inti Raymi festival, that pay respect to the Inca past and cultural heritage. The angle of the photograph in Fig. 6, taken by renowned photographer Allain Chambi, conveys the panorama of the festivities: the mountaintop and the clouds appearing from above and behind indicate the location-high up in the Andes. The crowd attending is nested in the curved polygonal walls that distinguish Inca architecture, as it observes from above the performers, who are dressed in replicas of Inca attires. But Inca ruins are of interest in and of themselves as venerated objects of the national patrimony and are often foregrounded in pictures that do not have any people in them. The frequency of postcard representations of indigenous people and Inca ruins is certainly connected in part to the development of mass tourism. However, it also reflects the public consolidation of a popular-assimilationist nationalism that glorified Peru's Andean roots and drew a direct link between precolonial past and contemporary national identity.

\section{The Nation on Argentine Postcards}

In sharp contrast to Mexico and Peru, postcards published in mid-twentieth-century Argentina continued to reproduce a liberal-elitist conception of nationhood that associated membership in the national community with wealth and whiteness. The results of our content analysis presented in Fig. 1 are indicative of an understanding of Argentina as a predominantly affluent, modern, urban, and racially white nation.

Postcard pictures foregrounding inanimate motifs remain infatuated with prosperity. As illustrated by the postcard reproduced in Fig. 7, Argentina is visually represented as a wealthy nation of modern and imposing cityscapes - avenues, vehicles, large buildings - found first 
Fig. 7 Buenos Aires - Darsena Norte (Buenos Aires - Northern Dock), Creationes S. Aguilera, Ed. La Sudamericana, postally used in 1956. Source: Authors' collection

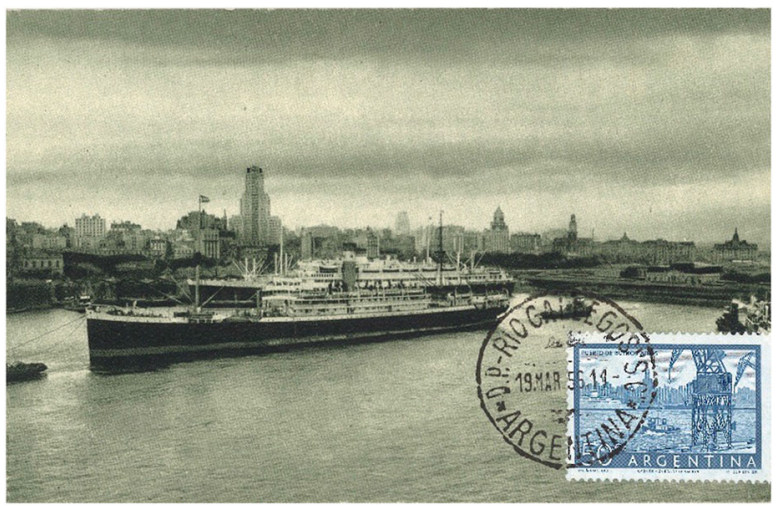

and foremost in Buenos Aires, with its stately architecture, and the broader metropolitan area, including the military and commercial port. This focus on wealth and modern urbanity is further reinforced through the choice of perspective. A significant number of the pictures take an elevated, bird's eye or even aerial perspective, which emphasizes the size of particular buildings or industrial sites, but also showcase the achievements of urban planning, as, for example, reflected in the innate order and organization of major city boulevards.

Eye-level or slightly elevated pictures that depict smaller streets or avenues similarly convey an impression of wealth, though through other means: They showcase neat squares, lined up with flowers and custom-cut bushes, fully electrified city squares, and automobiles on asphalt roads. Likewise, inanimate objects from the colonial or precolonial period remained largely absent from postcards. Only an insignificant percentage of postcards foregrounds colonial architecture, including religious sites, and there are no representations of Argentina's built precolonial heritage.

Our analysis further indicates that the celebration of peasants and workers was largely confined to state-sponsored materials such as school textbooks but did not enter the commercial production of postcards and hence the broader public sphere. People shown on postcards from mid-twentieth-century Argentina are predominantly affluent. Unnamed persons usually exhibit traits-whether those are the clothes they wear, the activities they pursue, or the locations they find themselves in - that mark them as part of the urban upper-middle class, while we only find scant images of peasants and workers. In fact, many postcards display ports, oil wells, water mills, cranes, and the like to showcase the material wealth of Argentina, but the people operating those machines and infrastructure remain largely invisible. Moreover, in terms of ethnicity, we find very few visual representations of non-white, mixed race, or indigenous Argentines. ${ }^{21}$ Another contrast to mid-twentieth-century Mexico is that a considerable number of postcards in Argentina depict political elites and military men, and increasingly also sportsmen, scientists, and explorers. Rather than standing for a particular collective, these men are recognizable as individuals, not the least because many are explicitly named in the postcard captions.

The geographic location of postcard motifs is heavily tilted towards Buenos Aires. This said, we still find examples of other urban centers, such as the tourist city of Mar del Plata

\footnotetext{
${ }^{21}$ It bears emphasis that in both mid-twentieth-century Mexico and Argentina, postcards did not include pictures of the racially black or Asian parts of the population, indicative of an understanding of nationhood that did not envision black or Asian Mexicans and Argentines as part of the nation (Loveman 2014; Knight 1994).
} 
Fig. 8 Mar del Plata - Playa Bristol y Casino, ca. 1950s. Source: Authors' collection

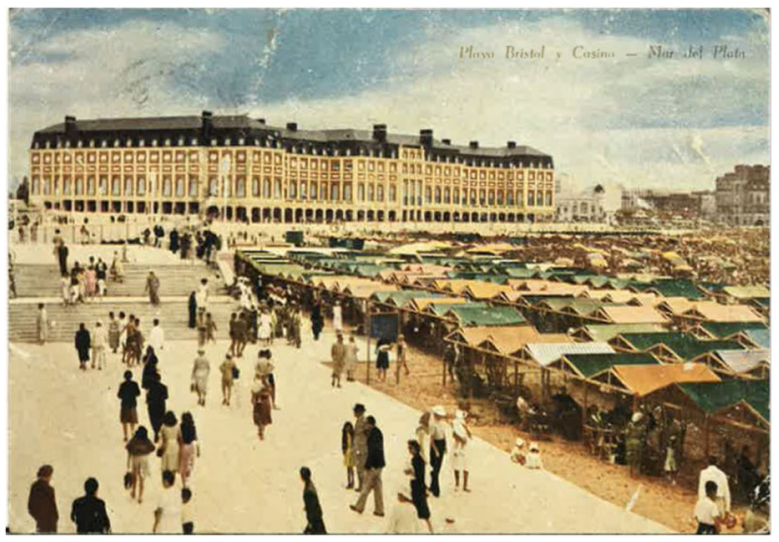

shown on the postcard in Fig. 8. Similar to Cuernavaca in Mexico, shown in Fig. 4, here too a majestic building can be seen in the background - the iconic Casino Central, though in this case, it is the building that constitutes the most dominant element (as is signaled also by the caption). The truly imposing proportions of the casino, which was relatively new at the time, stand as a testament to Argentine affluence. The promenade stretching across the beach complements this effect with its perfect white pavement and the large, capacious steps leading up to the building. The frame is nonetheless broad enough so as to incorporate people enjoying their stroll on the beach, dressed in fashionable garments, with sunglasses, hats, and handbags. The thematic of mass leisure can be interpreted as an attempt to showcase the growing Argentine middle class, yet it contrasts sharply with the vision of nationhood centered on workers that Peronist school textbooks sought to promote.

\section{Conclusion}

Inspired by an institutional approach to cultural analysis and Gramsci's theory of cultural hegemony, this article has developed a conceptual framework to understand how statesponsored nationalism is expressed and enacted in public life more broadly. Specifically, we have argued that the public consolidation of a new (or changed) official national ideology is indicated by both state-led imposition and liberal circulation. Consolidation involves particular nationalist contents becoming embedded in the organizational routines of state organizations and the regulation of cultural production. But consolidation also means that new ideological contents appeal to, and are therefore promoted by, a wider range of culture producers situated outside the domain of immediate state control.

Equipped with this conceptual framework, we have explored the consolidation of a new official nationalism in mid-twentieth-century Mexico, Peru, and Argentina. Our empirical research strategy has been focused on combining a novel set of primary sources. We have drawn on a content analysis of school textbooks to show that all three countries witnessed the state-led imposition of a popular-assimilationist national ideology. Based on a visual content analysis of picture postcards, we further demonstrated that liberal circulation of this new official nationalism varied. In Mexico and, to a somewhat lesser extent, Peru, these transformed representations of the nation were expressed and enacted more broadly in the public sphere, while they did not take hold in Argentina. 
Our main aim thus has been to conceptualize and identify variations in the consolidation of nationalism in these three Latin American countries. An important question that remains to be addressed is what factor (or combination of factors) accounts for these differences. Existing bodies of work suggest a number of promising leads. ${ }^{22}$ Some scholars focus on geopolitical conditions and argue that state-led imposition and active consent to a new homogenizing national ideology are more likely in countries confronted by an (perceived) existential threat to their territorial integrity (Mylonas 2013; Darden and Mylonas 2016). Another analytical focal point are domestic political configurations. The literature on revolutions emphasizes that revolutionary contexts are conducive to the consolidation of new political ideologies (e.g., Moaddel 2001; Skocpol 1979), whereas others point to state strength as decisive for the extent to which new ideological contents are expressed and enacted in public culture (e.g., Colburn and Rahmato 1992). Finally, scholars also have cited the importance of market-driven processes of ideological change, suggesting that a homogenizing nationalism is more likely in countries with a "mature" cultural industry and thus the capacity to foster unified spaces of communication and mass consumption (cf. Anderson 1991[1983]).

While it is for future research to empirically assess these different approaches and develop a full-fledged explanation, we consider a theoretical focus on intrastate relations and the relative timing of state institutional development as the most promising lead (vom Hau 2008, 2019). Specifically, we hypothesize that a new national ideology consolidated when state leaders had significant leverage over the construction of the state cultural machinery and could also rely on the support of local state actors tasked with socializing citizens or otherwise disseminating official ideological projects. By contrast, a new national ideology remained fiercely contested when state elites confronted a cultural machinery already established with fixed routines and radiating actors that opposed the new official nationalism.

Empirically, this explanatory approach yields promising insights: In Mexico during the 1930s, the state cultural machinery underwent a dramatic expansion. State elites constructed thousands of new schools, extended radio broadcasting across the country, and sponsored archeological excavations, mural paintings, and music festivals, all with the aim to create a popular homogenous national identity. Public school teachers, together with a group of state-supported artists and writers, saw themselves as the vanguard of the post-revolutionary regime. In Argentina during the 1940s, Perón sought to consolidate the new popular-assimilationist nationalism in a markedly different context. Public education, mass communication, and state-supported art production were already well-institutionalized, and the majority of teachers and other radiating actors vigorously opposed the new national ideology. In Peru during the 1970s, Velasco encountered a state apparatus with deeply entrenched routines of reproducing liberal-elitist nationalism, but also found strong within-state support for popular nationalism.

Moving beyond the comparative historical analysis of Mexico, Peru, and Argentina, the article highlights how official national ideologies compete with alternative representations of the nation and have different degrees of hegemony depending on context. Studying what kind of nationalism is promoted by state leaders and exploring its consolidation in the public sphere are two different tasks that require distinct analytical strategies. Our focus on textbooks and postcards illustrates one possible

\footnotetext{
${ }^{22}$ When compared to the large and influential literature on the origins of nationalism, transformations of nationalism over time so far have received more limited scholarly attention (Itzigsohn and vom Hau 2006).
} 
way to approach this methodological challenge, especially when conducting historical research on nationalism.

At the same time, there are limitations to what textbooks and postcards reveal. Both are - to an important extent-context-specific sources whose application to other time periods and locations might be limited and/or require important adjustments in research design. The use of textbooks to trace the state-led imposition of nationalism presupposes that the central state holds some control over education. This means that the systematic decentralization of national education systems, together with the massive privatization of schooling that swept Latin America for the last decades, has turned textbooks into a less reliable analytical window. Similarly, the use of postcards to explore the public circulation of state-sponsored national ideologies rests on the relative absence of state interference in postcard production. While we did not find evidence of direct state control or even censorship over postcard markets for twentieth-century Latin America, this might be different in other settings, such as Imperial Russia and later the Soviet Union (Rowley 2013), where state interference in postcard production was substantial. Finally, it also bears emphasis that we have been limited by the relative scarcity of systematic empirical evidence on the perceptions and motivations of postcard producers in late nineteenth- to mid-twentieth-century Mexico, Peru, and Argentina.

While acknowledging its historical boundedness and empirical limitations, our research strategy does offer important returns for the study of nationalism, ideological change, and visual sociology. Images arguably play an ever more important role in the cultural construction of life, yet social scientific research on the visual domain remains somewhat underdeveloped. Of particular concern is the trade-off between rigor and interpretive depth (Pauwels 2010), especially in light of the inherent ambivalence of images and their contents. In response, we have developed an analytical framework that combines a content analysis of a large- $\mathrm{N}$ sample with interpretive methods. This iterative approach should provide researchers with an appropriate tool kit for the social scientific analysis of the visual.

Acknowledgements We are grateful to the participants in the work-in-progress lunch meetings of the IBEI Collective Identities Research Cluster, the panel on "Nation-Building, State-Making, and Mass Schooling" at the APSA 2019 Annual Meeting, and the ISOR Seminar at the Autonomous University of Barcelona (UAB). Particular thanks go to Avi Astor for insightful discussions and suggestions, our APSA discussants Kristin Fabbe and Agustina Paglayan for constructive feedback, the Fung Global Fellows Program at Princeton University, and the librarians at the Princeton University Library, where this all started. The usual disclaimers apply.

Funding Information The research leading to this study received funding from the Spanish Ministry of Research, Development, and Innovation under the Ayudas Ramón y Cajal incorporation programme held by Dr. Matthias vom Hau (RYC-2014-16774).

Open Access This article is licensed under a Creative Commons Attribution 4.0 International License, which permits use, sharing, adaptation, distribution and reproduction in any medium or format, as long as you give appropriate credit to the original author(s) and the source, provide a link to the Creative Commons licence, and indicate if changes were made. The images or other third party material in this article are included in the article's Creative Commons licence, unless indicated otherwise in a credit line to the material. If material is not included in the article's Creative Commons licence and your intended use is not permitted by statutory regulation or exceeds the permitted use, you will need to obtain permission directly from the copyright holder. To view a copy of this licence, visit http://creativecommons.org/licenses/by/4.0/. 


\section{References}

Adamovsky, Ezequiel. 2016. Race and class through the visual culture of Peronism. In Rethinking race in modern Argentina, eds. Paulina Alberto and Eduardo Elena, 155-183. New York: Cambridge University Press.

Alexander, Abel, and Luis Priamo. 2017. Photography of views and customs in nineteenth-century Argentina. In Photography in Argentina: Contradiction and continuity, eds. Idurre Alonso and Judith Keller, 235-248. Los Angeles: Getty Publications.

Anderson, Benedict. 1991[1983] Imagined communities: Reflections on the origin and spread of nationalism. Revised version. New York: Verso.

Antonsich, Marco. 2016. The 'everyday' of banal nationalism - Ordinary people's views on Italy and Italian. Political Geography 54: 32-42.

Bayly, Christopher Alan. 2004. The birth of the modern world, 1780-1914. Oxford: Blackwell.

Berezin, Mabel. 1991. The organization of political ideology: Culture, state, and theater in fascist Italy. American Sociological Review 56: 639-651.

Billig, Michael. 1995. Banal nationalism. London: Sage.

Breuilly, John. 1982. Nationalism and the state. New York: St. Martin's Press.

Brubaker, Rogers. 2004. Ethnicity without groups. In Ethnicity without groups. Cambridge: Harvard University Press.

Brubaker, Rogers, Margit Feischmidt, Jon Fox, and Liana Grancea. 2006. Nationalist politics and everyday ethnicity in a Transylvanian town. Princeton: Princeton University Press.

Buchholz, Annika. 2015. Photography without borders: Max T. Vargas' impact as a studio photographer, artist and entrepreneur in southern Peru. In Explorers and entrepreneurs behind the camera, ed. Gregor Wolff, 126-134. Berlin: Ibero-Amerikanisches Institut.

Calhoun, Craig. 1997. Nationalism. Minneapolis: University of Minnesota Press.

Colburn, Forrest D., and Dessalegn Rahmato. 1992. Rethinking socialism in the third world. Third World Quarterly 13: 159-172.

Collier, David, and Ruth Berins Collier. 1991. Shaping the political arena. In Critical junctures, the labor movement, and regime dynamics in Latin America. Princeton: Princeton University Press.

Darden, Keith, and Harris Mylonas. 2016. Threats to territorial integrity, national mass schooling, and linguistic commonality. Comparative Political Studies 49: 1446-1479.

Eastwood, Jonathan. 2004. Positivism and nationalism in 19th century France and Mexico. Journal of Historical Sociology 17: 331-357.

Edensor, Tim. 2002. National identity, popular culture and everyday life. London: Bloomsbury.

Fox, Jon, and Cynthia Miller-Idriss. 2008. Everyday nationhood. Ethnicities 8: 536-563.

Fox, Jon, and M. van Ginderachter. 2018. Introduction: Everyday nationalism's evidence problem. Nations and Nationalism 24: 546-552.

Gellner, Ernest. 1983. Nations and nationalism. Ithaca: Cornell University Press.

Giordano, Mariana. 2009. Nación e identidad en los imaginarios visuales de la Argentina. Siglos XIX y XX. Arbor 185: 1283-1298.

Gorski, Philip S. 2003. The disciplinary revolution: Calvinism and the rise of the state in early modern Europe. Chicago: University of Chicago Press.

Grady, John. 2008. Visual research at the crossroads. Forum Qualitative Sozialforschung / Forum: Qualitative Social Research. https://doi.org/10.17169/fqs-9.3.1173

Gramsci, Antonio. 1971. [1929-1937]. The prison notebooks. New York: Columbia University Press.

Greenfeld, Liah. 1992. Nationalism: Five roads to modernity. Cambridge: Harvard University Press.

Guevara Escobar, Arturo. 2015. El origen de la tarjeta postal en Mexico. http://losprotagonistas-tarjetaspostales. blogspot.com/search/label/Introducci\%C3\%B3n?\&max-results=3. Accessed 7 July 2020.

Hobsbawm, Eric. 1990. Nations and nationalism since 1790. Programme, myth, reality. Cambridge: Cambridge University Press.

Hobsbawm, Eric, and Terence Ranger. 1983. The invention of tradition. New York: Cambridge University Press.

Itzigsohn, José, and Matthias vom Hau. 2006. Unfinished imagined communities: States, social movements, and nationalism in Latin America. Theory and Society 29: 193-212.

Jolly, Jennifer. 2018. Creating Pátzcuaro, creating Mexico: Art, tourism, and nation building under Lázaro Cárdenas. Austin: University of Texas Press.

Judson, Peter M. 2006. Guardians of the nation: Activists on the language frontiers of imperial Austria. Cambridge: Harvard University Press.

King, Jeremy. 2002. Budweisers into Czechs and Germans: A local history of bohemian politics. Princeton: Princeton University Press. 
Knight, Alan. 1994. Peasants into patriots: Thoughts on the making of the Mexican nation. Mexican Studies 10: $135-162$.

Knott, Eleanor. 2016. Everyday nationalism. Studies on National Movements (SNM) http://snm.nise.eu/index. $\mathrm{php} /$ studies/article/view/0308s

Lears, T.J. Jackson. 1985. The concept of cultural hegemony: Problems and possibilities. The American Historical Review 90: 567-593.

Lizardo, Omar. 2017. Improving cultural analysis: Considering personal culture in its declarative and nondeclarative modes. American Sociological Review 82: 88-115.

Loveman, Mara. 2014. National colors: Racial classification and the state in Latin America. Oxford: Oxford University Press.

Mahoney, James. 2010. Colonialism and postcolonial development: Spanish America in comparative perspective. New York: Cambridge University Press.

Malešević, Siniša. 2019. Grounded nationalisms: A sociological analysis. Cambridge: Cambridge University Press.

McDonnell, T.E., C.A. Bail, and I. Tavory. 2017. A theory of resonance. Sociological Theory 35: 1-14.

Miller-Idriss, Cynthia. 2009. Blood and culture: Youth, right-wing extremism, and national belonging in contemporary Germany. Durham: Duke University Press.

Moaddel, Mansoor. 2001. Conditions for ideological production: The origins of Islamic modernism in India, Egypt, and Iran. Theory and Society 30: 669-731.

Mraz, John. 2009. Looking for Mexico: Modern visual culture and national identity. Durham: Duke University Press.

Mylonas, Harris. 2013. The politics of nation building: Making co-nationals, refugees, and minorities. New York: Cambridge University Press.

Onken, Hinnerk. 2014. Visiones y visualizaciones: La nación en tarjetas postales sudamericanas a fines del siglo xix y comienzos del siglo XX. Iberoamericana 56: 47-69.

Onken, Hinnerk. 2016. Collecting picture postcards of South America. In Oxford Research Encyclopedia of Latin American History. https://doi.org/10.1093/acrefore/9780199366439.013.314.

Osorio, Alejandra. 2007. Postcards in the Porfirian imaginary. Social Justice 34: 141-154.

Patterson, Orlando. 2014. Making sense of culture. Annual Review of Sociology 40: 1-30.

Pauwels, Luc. 2010. Visual sociology reframed: An analytical synthesis and discussion of visual methods in social and cultural research. Sociological Methods \& Research 38: 545-581.

Rodríguez-Bravo, Roxana, and Juan Salvador Rivera-Sánchez. 2017. Los tipos mexicanos de aguadores y aguadoras en la fotografía del siglo XIX: representaciones y estereotipos de género. Agua y Territorio 9: 74-82.

Rose, Gillian. 2001. Visual methodologies: An introduction to the interpretation of visual materials. Thousand Oaks: SAGE.

Rowley, Allison. 2013. Open letters: Russian popular culture and the picture postcard, 1880-1922. Toronto: University of Toronto Press.

Schissler, Hanna, and Yasemin Soysal. 2005. Introduction: Teaching beyond the national narrative. In The nation, Europe and the world: Textbooks and curricula in transition, eds. Hanna Schissler and Yasemin Soysal, 1-12. New York: Berghahn Books.

Semmerling, Tim Jon. 2004. Israeli and Palestinian postcards: Presentations of national self. Austin: University of Texas Press.

Skey, Michael. 2011. National belonging and everyday life: The significance of nationhood in an uncertain world. London: Palgrave Macmillan.

Skocpol, Theda. 1979. States and social revolutions: A comparative analysis of France, Russia, and China. Cambridge: Cambridge University Press.

Smith, Anthony. 1986. The ethnic origins of nations. Oxford: Blackwell.

Surak, Kristin. 2012. Making tea, making Japan: Cultural nationalism in practice. Redwood City: Stanford University Press.

Van Dijk, Teun A. 1998. Ideology: A multidisciplinary approach. London: SAGE.

Van Ginderachter, Maarten. 2019a. The everyday nationalism of workers: A social history of modern Belgium. Redwood City: Stanford University Press.

Van Ginderachter, Maarten, and Jon Fox. 2019b. Introduction: National indifference and the history of nationalism in modern Europe. In National indifference and the history of nationalism in modern Europe, eds. Maarten van Ginderachter and Jon Fox, 1-32. New York: Routledge.

Vaughan, Mary Kay. 1997. Cultural politics in revolution: Teachers, peasants, and schools in Mexico, 19301940. Tucson: University of Arizona Press.

vom Hau, M. 2008. State infrastructural power and nationalism: Comparative lessons from Mexico and Argentina. Studies in Comparative International Development 43: 334-354. 
vom Hau, M. 2009. Unpacking the school: Textbooks, teachers, and the construction of nationhood in Mexico, Argentina, and Peru. Latin American Research Review 44: 127-154.

vom Hau, M. 2015. From 'civilizing force' to 'source of backwardness': Representations of Spanish colonialism in Latin America. Revista de Historia Actual 37: 117-133.

vom Hau, M. 2019. The developmental state and the rise of popular nationalism: Cause, coincidence, or elective affinity? In State and nation making in Latin America and Spain volume II: Rise \& fall of the developmental state, eds. Miguel Centeno and Agustín Ferraro, 317-345. New York: Cambridge University Press.

Weber, Eugen. 1976. Peasants into Frenchmen: The modernization of rural France, 1870-1914. Redwood City: Stanford University Press.

Wimmer, Andreas. 2002. Nationalist exclusion and ethnic conflict: Shadows of modernity. Cambridge: Cambridge University Press.

Wimmer, Andreas. 2018. Nation building: Why some countries come together while others fall apart. Princeton: Princeton University Press.

Wuthnow, Robert. 1989a. Communities of discourse. Ideology and social structure in the reformation, the enlightenment, and European socialism. Cambridge: Harvard University Press.

Wuthnow, Robert. 1989b. Meaning and moral order: Explorations in cultural analysis. Berkeley: University of California Press.

Zahra, Tara. 2008. Kidnapped souls: National indifference and the battle for children in the bohemian lands, 1900-1948. Ithaca: Cornell University Press.

Publisher's Note Springer Nature remains neutral with regard to jurisdictional claims in published maps and institutional affiliations.

Anna Kyriazi is a Postdoctoral Research Fellow at Università degli Studi di Milano ("La Statale"). She holds a $\mathrm{PhD}$ in sociology from the European University Institute (2017) and was a postdoctoral researcher at the Institut Barcelona d'Estudis Internacionals (IBEI). Her main areas of interest are comparative ethnicity and nationalism, minority rights, and political communication.

Matthias vom Hau is an Associate Professor and Ramón y Cajal Researcher at the Institut Barcelona d'Estudis Internacionals (IBEI). A sociologist by training, he has a PhD (2007) from Brown University and previously held a postdoctoral fellowship at the University of Manchester. Matthias' research is centrally concerned with the relationship between identity politics, institutions, and development. 